\title{
DIE SUID-AFRIKAANSE STAD AS RUIMTELIKE BASIS VIR 'N INSURGENTE- STAAT
}

Kapt C.C. Scheepers*

\begin{abstract}
Persoonlike menings in die loop van 'n artikel uitgespreek, word nie noodwendig deur die SAW onderskryf nie.
\end{abstract}

Opinions expressed by individual contributors do not necessarily reflect the official viewpoint of the SADF.

Increasing urbanization is an important reason for the shift in accent of guerrilla activities. On the one hand the politically unsophisticated inhabitants of the rural areas are not ripe for revolution and on the other hand technological developments of the past few decades have detrimentally influenced the position of the guerrilla in this area. The South African city as spatial base for an insurgent state is analysed and discussed in the article below.

\section{Inleiding}

Na die Tweede Wêreldoorlog het rewolusionêre oorlogvoering vinnig ontwikkel, veral op die model soos deur Mao tse-Tsung uiteengesit. Mao se benadering was egter hoofsaaklik plattelands gerig; die ontevrede kleinboere wat deur die militêre baronne uitgebuit is het ' $n$ vrugbare teelaarde vir Mao se guerrillamagte geword. Toestande in die res van die wêreld, veral die Derde Wêreld, is sodanig dat bevolkings teen ' $n$ ongekende en angswekkende tempo verstedelik raak. Dié tendens veroorsaak ook 'n groot probleem in Latyns-Amerika waar Sao Paolo se bevolking byvoorbeeld met $8,5 \%$ per jaar toeneem. (Dwyer, 1978). Die toename in verstedeliking is ' $n$ belangrike rede waarom guerrilla-aktiwiteite ' $n$ klemverandering ondergaan het. Enersyds is die polities ongekunstelde bevolkings van die platteland nie ryp vir rewolusie nie en bestaan daar in die Suid-Afrikaanse geval ' $n$ beter verhouding tussen Blank en Swart op die platteland. Andersyds het tegnologiese ontwikkelings in die afgelope paar dekades die guerrilla se posisie op die platteland nadelik beïnvloed. (Coetzee, 1981).

Die Kubaanse rewolusie kan waarskynlik as die belangrikste keerpunt in guerrilla-oorlogvoering beskou word. Sedert dié tydperk het verskeie denkers tov stedelik terrorisme op die voorgrond getree, onder andere mense soos Ché Guevara, Regis Debray, Herbert Marcuse, Abraham Guillén en Carlos Marighella. Guevara se invloed in stedelike terrorisme het ironies genoeg eers ná sy dood tot sy reg gekom. (Theron, 1976). Guevara was 'n groot navolger van Mao tse-Tsung, alhoewel hy in 'n paar opsigte sy teorie moes aanpas by die situasie in Kuba. Mao het byvoorbeeld verkondig dat stede as ' $n$ laaste vesting gelos moet word, terwyl Guevara stedelike oorlogvoering in die guerrillafase voorsien het. Guevara het stedelike terrorisme egter as ' $n$ aanhangsel van die plattelandse guerrillastryd gesien, deurdat eersgenoemde stryd deur die plattelandse beweging gekoördineer moes word. (Lass, 1975; Theron, 1976). Anders as Mao het Guevara nie geglo dat op ' $n$ gunstige klimaat vir rewolusie gewag moet word nie - so 'n klimaat moet geskep word. (Lass, 1981). Guevara stel dan voor dat stedelike operasies met vier tot vyf man bedryf moet word wat met karabyne, pistole en afgesaagde haelgewere hul aksies voortsit. Sorg moet egter gedra word dat terreur nie teen die bevolking gepleeg word nie aangesien dit hul steun sal vervreem. Guevara het na die suksesvolle rewolusie in Kuba sy idees en leiding na Latyns-Amerika oorgedra. (Theron, 1976).

Régis Debray was sterk deur Guevara se denke beïnvloed en het self ook ' $n$ groot bydrae tot stedelike rewolusionêre denke gemaak in publikasies soos Strategy for Revolution (1970 gepubliseer) en Revolusion in the Revolution. Sy siening was dat Universiteite en stedelike 'ghettos' die fokuspunt van die stedelike terroris moet word. Sy grootste bydrae is die rol wat hy vir die student en die intellektueles voorsien het in hierdie stryd. (Theron, 1976; Lass, 1981). Die rol van dié groepe sal later onder stedelike oproer in Suid-Afrika bespreek word. Marcuse het Debray gesteun in die rol wat hy vir die linkse student voorsien het. As geswore Marxis het hy dan ook groot invloed onder linkse studente in Amerika gehad. (Theron, 1976). Marcuse was egter 'n filosoof en het geen praktiese handleiding daargestel wat as riglyn van stedelike operasies kon dien nie. Die eerste handleiding het uit Carlos 
Marighella se pen gevloei. In sy 'Minimanual of the Urban Guerrilla' wat in Junie 1969 verskyn het, het hy die praktiese aspekte van stedelike operasies uiteengesit; dit wissel van die motivering tot die werkswyse wat gevolg moet word ten einde sukses te bereik. Marighella het op 4 November van dieselfder jaar gesterf, voordat die praktiese uitvoering in alle aspekte uitgetoets kon word. (Theron, 1976; Marighella, 1969).

Marighella was, net soos Guevara, 'n navolger van Mao wat stedelike en plattelandse aksies gekoördineerd gesien het in die stryd teen die militêre regering in Brasilië. Marighella het in die stede doelgerigte aksie teen die regering bepleit. Die bevolking moes gerespekteer word. Volgens Marighella moet die stedelike guerrilla baie dapper en vasbeslote van aard wees, wat op eie inisiatief en met die verrassingselement aan sy kant, sonder enige leiding moet kan toeslaan. Hy moet die beweging se saak by die bevolking versterk. In sy Minimanual het hy onder andere die vervaardiging van verskillende wapentuig verduidelik, klem gelê op kennis van sy terrein, hoe mobiliteit en spoed benut moet word, hoe om dokumente te vervals, watter doelwitte nagestreef moet word en hoe groepe georganiseer moet word. (Marighella, 1969). Van die denkers wat tot dusver bespreek is, kan afgelei word dat Guevara en Marighella teoreties en prakties ingestel was, terwyl die ander maar op die filosofie van stedelike guerrilla-oorlogvoering gekonsentreer het. Vervolgens sal die Suid-Afrikaanse situasie bespreek word.

\section{Die Suid-Afrikaanse (SA) Stad}

\section{Struktuur}

Die skeiding tussen etniese groepe in SuidAfrika is ' $n$ historiese kenmerk van die sosiale, ekonomiese en ruimtelike organisasie van die SA stad. Gebiedskeiding dateer sedert enkele jare ná die Volksplanting aandie Kaap en dit het geleidelik na die binneland uitgebrei. Die ontdekking van diamante in 1869 en goud aandie Witwatersrand in 1888 het tot ' $n$ toenemende stroom Swartes na Blanke gebiede gelei. Die Blanke het die gunstige posisie naby die dorpskern beset terwyl die Swartes periferies gevestig was op 'n gebied met laer grongwaarde. Die Suid-Afrikaanse stad is uniek in dié sin dat dit terselfdertyd eienskappe van 'n Westerse en 'n Derde Wêreldse, koloniale stad openbaar. Die sentrale sakekern en sy funksies, die ruimtelike verspreiding van industrieë ens stem met die van die
Weste ooreen. Residensieel toon dit 'n ooreenkoms met ' $n$ vreemde stad. Weens die wye sosiale gaping, etnies verskille en verskille in tegnologiese ontwikkeling tussen die onderskeie etniese groepe, is die Segregasiestad gebore. Op ' $n$ tydskaal aangestip, het die tipe stad tot die laat veertigerjare ontwikkel en hieruit is die Apartheidstad gebore (Davies). Vervolgens word na bogenoemde twee tipes stede gekyk.

\section{Die Segregasiestad}

Davis het Durban as ' $n$ voorbeeld van ' $n$ segregasiestad aangehaal. Struktureel bestaan 'n segregasiestad uit die volgende komponente:

i. 'n Dominante Wit sentrale sakekern (SSK);

ii. 'n periferiese ligging vir Indiër- en Chinese besigheidsentra;

iii. industriële sektore binne die blanke invloedsfeer;

iv. Blanke residensiële gebiede op die beste grond;

v. sentraal geleë Anderskleurige residensiële gebiede binne ouer Blanke gebiede;

vi. Swart en Indiër-woongebiede, barakke en kampongs op die periferie; en

vii. laastens, oorgangsones waar Swartes die ouer Blanke gebiede infiltreer.

Hieruit kan afgelei word dat Blankes ' $n$ dominante posisie beklee het tov woongebiede en afstand vanaf die SSK. Namate vervoermiddele verbeter het en Blanke stedelike bevolkingsgetalle toegeneem het, het die Blankes radiaal uitwaartes gekring en in baie gevalle hul buite die Swart residensiële gebied gevestig. Davis (1964) het die ooreenkoms tussen Amerikaanse en Suid-Afrikaanse stede aangetoon. Daarenteen was Swart behuising ontoereikend en hul vestiging net toegelaat om ongeskoolde arbeid aan die Blanke ekonomie en huishouding te verskaf. Die 1923 Wet (Nature Urban Areas Act) het voorsiening gemaak vir lokasies. Die 1945 wet het strenger segregasiemaatreëls voorgeskryf wat veral die instroming van Swartes beheer het. Toenemende getalle immigrante uit die platteland het tot behuisingstekorte gelei en toestande het verswak. Plakkerhuisies het in die proses op private en openbare gebiede in die stedelike periferie verrys. Maasdorp en Humpneys (1975) het geskat dat $34 \%$ van die Swart bevolking om Durban in 1957 so gevestig was. (Davis).

In die Durban-gebied het die Indiërs 'n spesifieke 'bedreiging' vir Blankes ingehou itv handel. Verskeie statute en munisipale wette het hul mobiliteit in Blanke gebiede beperk. Die 'Asiatic 
Land Tenure Act' van 1946 het Indiërsegregasie in Natal en Transvaal gewettig. In die Kaapse Skiereiland het Kleurlinge in die ouer Blanke gebiede infiltreer. Daar het egter ondanks hierdie verskynsel nog ' $n$ groot mate van segregasie bestaan. Met die Nasionale Party oorname in 1948, het die regerende party geredeneer dat kontak tussen rassegroepe tot konflik lei. Die Groepsgebiedswet van 1950 het die weg vir die Apartheidstad gebaan. (Davis; Scott, 1955).

\section{Die Apartheidstad}

Harmonieuse verhoudings tussen rassegroepe is as hoogs onwaarskynlik beskou en die persepsie was om kontakpunte tot ' $n$ minimum te beperk. Sosiaal en ruimtelik is daar ' $n$ onderskeid getref, met die Blanke steeds sentraal en die Swarte op die periferie gevestig. Dit het tot hoogs gestruktureerde verbreiding gelei. Spesifieke gebiede is vir Swart stedelike ontwikkeling afgebaken en met fisiese en mensgemaakte strukture van die Blanke gebiede geskei. Waar tuislandgrense na aan Blanke gebiede geleë is, soos byvoorbeeld Pretoria, is stedelike gebiede hier ontwikkel wat makliker met die hinterland kan skakel.

Beweging van Swart groepe (pendelaars) is so gereël dat dit tot 'n minimum kontak tussen groepe lei. Om konflik uit te skakel het Swartes nie direkte toegang tot industriële en nie-residensiële gebiede gekry nie. Die Blanke bevolkingsgroep, soos in die segregasiestad, het maklik toegang tot die stad; terwyl Swartes 'n heelwat langer reisafstand het wat hoër kostes impliseer. Die bewoners van die Swart stede was hoofsaaklik eers mans wat in kampongs en losiehuise geakkommodeer is. Met die koms van die swart vrou het die situasie verander.

Dit is eers onlangs (1980) dat Swartes volgens die 99 jaar huurpagstelsel huise mag besit, maar nie die grond waarop die gebou is nie. (Smit; Booysen, 1981). Die Apartheidstad het die kernperiferie-verhouding van die Segregasiestad verder intensifiseer. Met dié strukturele prentjie in gedagte gaan die skrywer nou poog om die toekomstige knelpunte uit te lig.

\section{Toekomstige Knelpunte}

As in gedagte gehou word dat die Derde Wêreldlande se stedelike bevolkings viervoudig sal toeneem oor die volgende twintig jaar, kan ge- sien word dat dit ' $n$ wêreldwye probleem is. Wat SA betref, is die belangrikste probleem die toenemende stedelike bevolkings Owerheidsbesteding aan behuising vir Swartes het tussen 1966 en 1969 R66 miljoen per jaar beloop. Tekorte tov behuising vir die bevolkingsgroepe beloop na raming (1977-syfer) ongeveer 310000 wonings. Tweedens het die koste om huise te bou, fenomenaal teogeneem. Derdens word plakkery ' $n$ groot maakskaplike probleem met gepaardgaande euwels soos misdaad, 'n tekort aan voldoende sanitasie- en rioleringsgeriewe. Plakkery is nie net ' $n$ probleem in Blank SA nie maar kom ook in die nasionale Swart state voor. Omdat daar so 'n groot woningnood bestaan, kan plakkery waarskynlik met sekere voorbehoude toegelaat word. Vierdens is die verwagting dat verstedliking tot ' $n$ toenemende mate sal plaasvind weens die stagnerende posisise van die landbou in die nasionale Swart state. Daar word geraam dat ongeveer 21 miljoen Swartes teen die wisseling van die eeu verstedelik sal wees. (Smit, 1981; Oosthuizen, 1979). Die implikasie van so ' $n$ toename is voor die hand. Vyfdens veroorsaak die snelgroeiende stede op die tuislandgrense dat die platteland ontvolk raak in dié gebiede. Sesdens trek die vier metropolitaanse gebiede, nl die PWV-gebied, Durban-Pinetown, Port Elizabeth-Uitenhage en die Kaapse Skiereiland $57 \%$ van die Swart stedelike bevolking, wat op slegs $4 \%$ va die land se oppervlakte gevestig moet word. Dáár moet die Swart bevolking groter mate van seggenskap oor hul eie aangeleenthede uitoefen, ten einde evolusionêr in adminstrasie en beheer geskool te word. (Smit, 1981). Laastens veroorsaak die groot aantal pendelaars (hoofsaaklik mans) dat dié Swart state ekonomies geknou word weens die onttrekking van mannekrag: dit werk nadelig op die tuislandbeleid in (Smit, 1979).

Bogenoemde is enkele knelpunte wat in gedagte gehou moet word, maar daar kan andere wees wat net so ' $n$ groot uitwerking op toekomstige ontwikkeling mag hê. Om hierdie afdeling af te sluit wil die skrywer 'n paar punte uitlig en beklemtoon. As die PWV-gebied as voorbeeld geneem kan word, kan in figuur 1 gesien word hoe Blank en Swart residensiële gebiede relatief tot mekaar geleë is. Stedelike terreur kan waarskynlik met ' $n$ redelike mate van sukses bedryf word indien dié bevolking militant opgesweep word. (Smit, 1981).

\section{Bron: Smit, 1981.}

Pendelaars wat daagliks tussen hul wonings in 


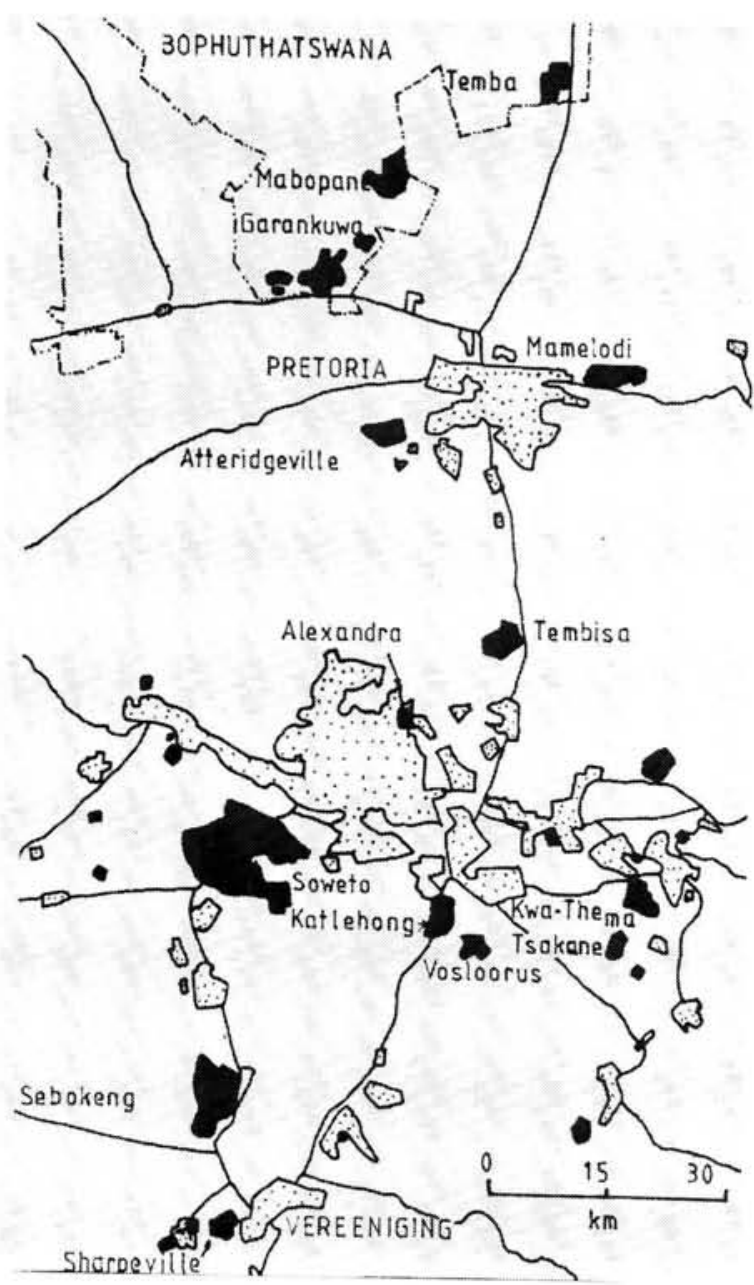

Figuur 1: Stedelike Swart Woongebiede in PWV

die Swart state en Blank SA beweeg, kan waarskynlik ' $n$ terroriste-toegangsroete tot die SSK industriële dele van die staat word. (Sien aanhangsel B vir die 1967 syfers tov pendelaarsgetalle.) Die toename van Swart stedelike bevolkings tussen 1960 en 1970 kan in aanhangsel C bestudeer word. Hier moet veral gelet word op die toename om die PWV-gebied en die Durbanomgewing; ander stedelike sentra het daarteenoor relatief stadiger gegroei. (Smit, 1981). Nog 'n aspek wat waarskynlik vir die stedelike guerrilla 'n skakeling met Swart state kan gee is die trekarbeid. Periodieke beweging van Swart migrante arbeiders, meestal mans, vind plaas soos figuur 2 dit na die Oos-Rand aandui.

\section{Implementering van Revolusie}

\section{Inleiding}

$\mathrm{Na}$ die beëindiging van die Tweede Wêreldoorlog is verskeie Swart organisasies in Suid-Afrika gestig om 'n rewolusionêre verandering in Suid-

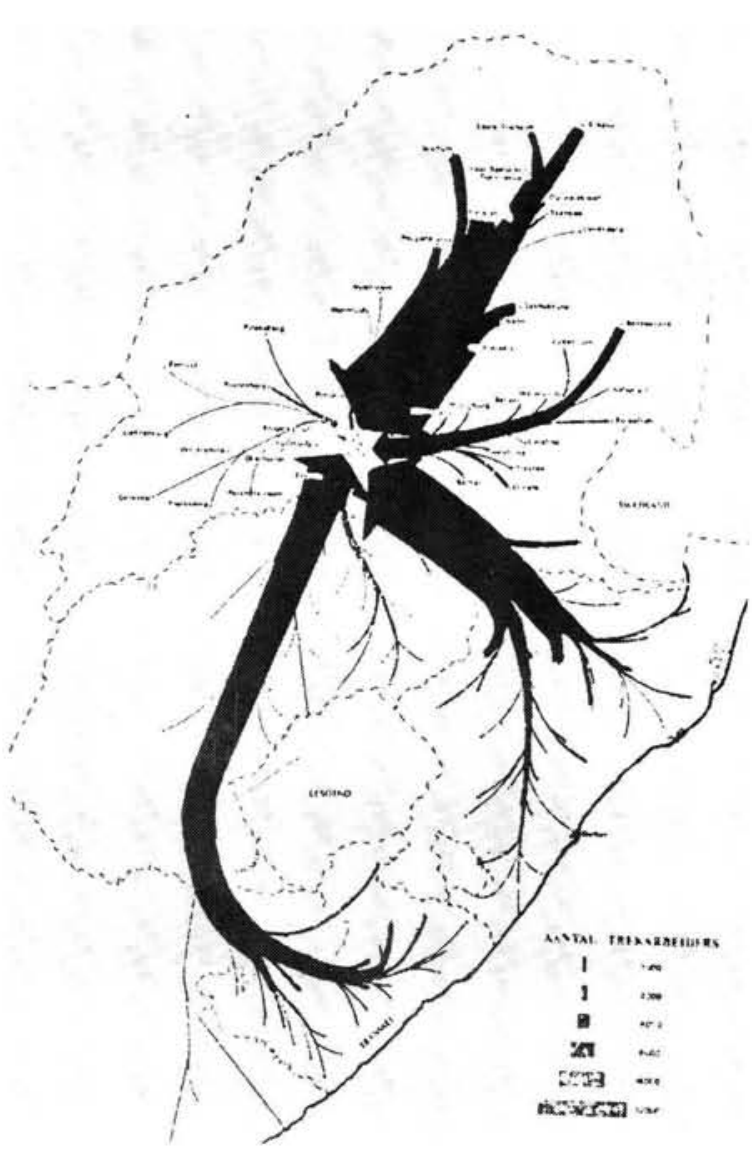

Figuur 2: Trekarbeiders na die Oos-Rand

Afrika teweeg te bring. Organisasies soos die African National Congress (ANC), wat reeds in 1912 ontstaan het, het in 1961 sy militante vleuel Umkonto we Sizwe gestig. Die Pan Africanist Congress (AC) het in 1958 ontstaan en sy militêre vleuel Poqo in 1961 bygekry. Die African Resistance Movement is in 1961 gestig. (Schutte, 1978). Baie kleinere organisasies het saamgesmelt om die organisasies te vorm waarvan die ANC en PAC die belangrikste is. Volgens dr L.D Barnard (1981) het die Black Consciousness Movement (BCMSA) in die afgelope tyd meer sukses as die ANC behaal. Die Swart bevolking blyk ongelukkig te wees oor Blanke lede in die ANC. (Afrika Instituut Bulletin, 1979).

\section{Die 'African National Congress'}

Die ANC het in 1912 ontstaan met die politieke ontwikkeling van die Swartman. Aanvanklik was hul doelstellings nie gewelddadig nie. Die SuidAfrikaanse Kommunistiese Party (SAKP) het mettertyd binne die organisasie ingesypel en Blankes is sedert 1947 toegelaat om lede te word. Op hierdie wyse het die ANC met ander organisasies ingeskakel en hul doel het die om- 
verwerping van die bestaande orde en gesag geword. Die Regering van die dag was bewus van dié verwikkeling, het opgetree en die ANC op 8 April 1960 'n onwettige organisasie verklaar. Dit het die ANC gedwing om sy werk ondergronds voort te sit en hier het die beplanning van ' $n$ rewolusie gestalte begin kry. Op ' $n$ vergadering is 'The Continuation Committee of African Leaders' gestig wat 'n nasionale konvensie op 31 Mei 1961 moes reël. (Schutte, 1978). Die ANC krag was egter effens afgetakel weens die afstigting van sommige van sy lede in 1958, en wat meer nasionalisties ingestel was en die PAC gevorm het. Hoe dit ook al sy, die ANC het met sy reorganisasie in veral die Oos-Kaap, in die geheim vergader. Dier struktuur van die ANC word vervolgens bespreek. (Feit, 1970).

\section{Struktuur}

Die sameroeper va die geheime vergadering stel 'n hooftoesighouer (Chief Steward) oor 'n bepaalde sone aan, en al die lede teenwoordig, word seltoesighouers. Die sone bestaan uit 'n aantal straatblokke en elke straat bestaan uit 'n sel. Die seltoesighouer is verantwoordelik vir die werf van sewe lede vir elke sel. Boontoe word die hiërargie opgehou na die streekskomitees. Die hooftoesighouer moet alle besluite van die streekskomitees weer na die laaste vlak terugvoer; die hooftoesighouer het egter geen kontak met die leier anders as deur 'n kontak nie. Streekskomitees word dus dmv kontakte aan die Nasionale Uitvoerende Komitee gekoppel. Die hiërargiese orde en kontakte is só ontwerp dat 'n enkele deel wel opgespoor kan word, maar nie die hele organisasie nie. Geheime vergaderings word ook op verskillende plekke gehou sodat opsporing van selle, ens bemoeilik word. 'n Swakheid van die stelsel is die werwing van lede: geen toets word afgeneem om die lid se bona fides te bepaal nie en sodoende word polisie-insypeling vergemaklik. (Feit, 1970).

Die ANC-poging om hul sogenaamde ' $M$ ' plan van Nelson Mandela te laat slaag, was nie baie suksesvol nie. Die selorganisasie soos bv. wat in die vyftigerjare ontwikkel het, moes nou met 'n meer kommunistiese orde, wat uit basies dieselfde struktuur bestaan het, vervang word. Die ANC-leierskap wat weens arrestasies en swak vertoning uitgeput was, het in Junie 1961 besluit om die 'Umkonto we Sizwe', die sogenaamde 'Spies van die Volk', te stig (Feit, 1970) wat op 16 Desember 1961 'n werklikheid geword het. (Coetzee, 1981).

\section{Umkonto we Sizwe}

Die meesterplan wat 'Umkonto we Sizwe' (UWS) beplan het, sou drie stadia behels: eerstens die opbou van die mag ondergronds, tweedens 'n vlaag van sabotasie terwyl van die lede in die buiteland opgelei word en laastens 'n volskaalse guerrilla-oorlogvoering op die Guevara-model geskoei. (Feit, 1970; Schutte, 1978). Om dit alles te bereik, is hul optredes as volg beplan: sabotasie sal teen regerinsgeboue en strategiese nywerhede geloods word, die swart massas polities gestimuleer word, buitelandse opgeleide terroriste gebruik word om leiding in die land voort te sit. Indien dit nie sou werk nie, sal tot 'n guerrillafase oorgegaan word. UWS het gehoop dat die skrikbewind die Blankes sou beweeg om die Swartes te steun. Indien die guerrillafase noodsaaklik blyk te wees, sou Kommunistiese troepe in die finale stadium ingryp om die regering tot 'n val te bring. (Feit, 1970; Coetzee, 1981). Met lede soos Joe Slovo, Harold Wolpe, Goldreich, Heppele, (blankes) Mandela, Sisulu, Mlangeni ens, het Operasie Mayibue vorm aangeneem. (De Villiers, 1964; Strydom, 1964).

\section{Die Tweede fase van Operasie Mayibuye}

Terwyl opleiding van terroriste in die buiteland plaasgevind het, het 'n vlaag van geweld die land in die vroeë sestigerjare getref. In die Port Elizabeth-omgewing is majoor O'Kelvie vermoor toe hy ANC lede wou stuit en bomontploffings het in Johannesburg, Durban en Kaapstad op 16 Desember 1961 voorgekom. Opstande het in Sharpeville en Langa plaasgevind. Die kommunisties geïnspireerde optrede het selfs na die Transkei uitgebrei. (Shay \& Vermaak, 1971). Bogenoemde is slegs enekele voorbeelde van geweld, maar daar kan afgelei word dat dit landwyd georganiseer was. Operasie Mayibuye is egter nooit voltooi nie, want op 11 Julie 1963 het die SAP die Rivonia-klopjag uitgevoer en die grootste gros van die leiers gevange geneem. (Coetzee, 1981). Dade van terreur het nog sporadies voorgekom soos die bomontploffing op 24 Julie 1964 op 'n vol Johannesburg-stasie. (Strydom, 1964).

Die ANC se aktiwiteite het egter nie hiermee tot stilstand gekom nie; die benaderingswyse het meer sielkundig van aard geword. Sedert 1975 het hulle weer aktief geword en hul rol in die Soweto-opstande (1976) sal later bespreek word. 


\section{Die Pan African Congress}

Dié organisasie het sy ontstaan te danke aan 'n skeuring van die ANC. Die PAC wat in April 1959 gestig is, het hul beywer vir die herlewing van Swart nasionalisme en die omverwerping van die regering. Die PAC se militêre vleuel wat as Poqo bekend staan, het in 1961 met onwettige vergaderings begin. Anders as die ANC, is die PAC en Poqo se leiers dieselfde mense. )Die twee name verwys dus na dieselfde beweging.) Poqo se doelstelling is om die Blankes en Asiërs deur moord en terrorisme die land uit te dryf. Verkryging van populêre Swart steun is ook een van die grootste doelstellings en selfs die inboeseming van vrees is gebruik om dit te bewerkstellig. Verder is lede van die organisasie aangemoedig om wapens in die hande te kry en self te vervaardig. (Schutte, 1978).

\section{Terroriste-aanslag}

Die aanslag wat deur Poqo geloods is, het ook in die vroeë sestigerjare plaasgevind. Volgens Schutte (1978) het dit op drie fronte plaasgevind: dade van terreur was toegespits op die Swart bevolking, die staat en Blankes. In eersgenoemde geval was die doel om te intimideer en Ig geval om die Blankes ooreenkomstig hul doelstellings bevrees te maak. Die dade teen die Blankes is met die grootste wreedheid toegepas. Aanvalle is onder andere in die Paarl, die Transkei, Johannesburg en King Williams Town gedoen. Daarbenewens was daar anti-pasboek opstande in Vereeniging en Kaapstad. Poqo se meesterplan om Suid-Afrika in 'n bloedbad te omskep, is egter deur die Polisie onderskep wat tot Robert Sobukwe en sy leierskader se arrestasie gelei het. Wat Poqo so gevaarlik gemaak het, is die feit dat hulle pogings aangewend het om die Blankes dmv hul bediendes te vergiftig en met ander metodes te vermoor. (Shay, 1971). In dié tydperk van geweld (Sept 1962-3 April 1963 ) is egter net tien Blankes vermoor en vier beseer, wat daarop dui dat die poging nie baie suksesvol was nie. (Schutte, 1978).

Ter nabetraging was die ANC en Pac optredes nie baie suksesvol nie. Uitgesonder die verlies aan menselewens, (wat onbetaalbaar is), was die skade in die Oos-Kaap ongeveer R120 000. (Feit, 1970). Met dié stukkie geskiedenis in gedagte, sal vervolgens op die ANC en PAC optredes in die onlangse verlede gelet word, veral tov Stedelike operasies

\section{Stedelike oproer in Suid-Afrika}

\section{Inleiding}

Die vlaag van stedelike opstande wat Suid-Afrika in 1976 getref het, word in die algemeen na verwys as die Soweto-opstande. Dit is egter 'n verkeerde opvatting aangesien die hele geografiese gebied van SA deur betogings, geweldpleging en onrus beetgepak was. Weens die groot omvang van die gebeurtenis, sal daar slegs na gebeure in Soweto en die Kaapse Skiereiland gekyk word.

\section{Tegnieke Aangewend}

$\mathrm{Na}$ die skrywer se interpretasie blyk dit heel eenvoudig te wees, $\mathrm{nl}$ om ' $\mathrm{n}$ massahisterie by Swartes te ontwikkel. Die ANC, PAC en ander groepe se bydrae sal later bespreek word. metodes wat gebruik is, was klipgooiery, brandstigting, aanranding, aanhitsing tot gewelddadige optrede, oprigting van padversperrings, stakings en boikotte teen skole en aanvalle teen die polisie (in persoon en op polisiestasies). ' $\mathrm{n} \mathrm{Be}$ langrike aspek van die opstande in Soweto en elders was die gebruikmaking van die kind. Tsietsi Mashini het bv die kinders aangemoedig om skole te boikot. Die tegniek om vroue en kinders tegebruik in klipgooiery en boikotaksies, is heel eenvoudig. Sou die polisie teen hulle optree, word die polisie voorgestel as die wrede monster van onderdrukking. Verdere tegnieke is om buitelandse simpatie te kry soos die betogings en gewelddadige optrede met dr Kissinger se besoek. (Cillie, 1977).

Ten einde die ekonomie te ontwrig, het die intimidasie van arbeiders vry algemeen plaasgevind. Veral die 'Tsotsi's' het hier 'n groot bydrae gelewer. Enige persoon wat saam met die polisie gewerk het, of om orde gepleit het, is geïntimideer, soos bv Swart konstabels wie se huise in Soweto afgebrand is. Om te verseker dat die jeugdiges hul terreur voortsit, is hulle in baie gevalle van sterk drank en petrol voorsien. Ten slotte kan genoem word dat die Swartmagsaluut voortdurend gebruik is om eenheid onder die Swartes aan te moedig. (Cillie, 1977).

Die tegnieke in die Kaapse Skiereiland is basies dieselfde. Die Kleurlinge, veral van die Universiteit van Wes-Kaapland, het hier leiding gegee deur hul meegevoel met Soweto te betuig. Swartmagslagspreuke is op die mure van skole in Blanke gebiede opgemerk. 'n Publikasie van die Universiteit van Wes-Kaapland, UWC-So- 
weto, wat in die Swart gebiede van Langa, Nyanga en Guguletu verskyn het, het opstandvure aan die brand gesteek. Cillie (1977) meen dat groepe soos die ANC en SAKP se rol moeilik vasgepen kan word. Bewyse van pamflette wat deur dié organisasies versprei was, is gevind. Hy meen egter dat die kern van die opstokers waarskynlik uit die ANC voortspruit.

\section{Relatiewe Suksesse}

$\mathrm{Na}$ die skrywer se mening het hulle die aandag van die wêreld op die 'wrede' (sic) onderdrukking van die Swartmense in stedelike gebiede gevestig. Daar is in geslaag om in sekere eise te slaag byvoorbeeld dat die voertaal nie meer Afrikaans moet wees nie. Verder meen hy dat die Blanke Suid-Afrikaner meer bewus gemaak is van die stedelike Swarte en die probleem wat sy teenwoordigheid verteenwoordig. Laastens, die 1976 opstande het baie persone vanaf die stede laat uitwyk na die buiteland. Dié mense sal beslis deur die ANC gebruik en opgelei word om die stryd later aan te knoop. (Coetzee, 1981).

\section{Toekomstige Ontplooiing}

Die stedelike gebiede in Suid-Afrika word deur insurgente leiers as maklike teikens beskou omdat in elke stedelike gebied duisende 'angry and oppressed Blacks' teenwoordig is binne 'n kort afstand daarvandaan. (Hitchcock, 1973). Hoe die stryd in die stede gaan verloop, kan slegs oor gespekuleer word. Een van die terroriste se grootste doelwitte is publisiteit. Soos Coetzee (1979) dit gestel het '... a terrorist in the West has a 50 persent chance of having some or all his demands met, an 80 persent chance of escaping death or capture, and a 100 persent chance of getting the publicity he sought.' Daar kan verwag word dat enige staking deur ' $n$ Swart vakbond waarskynlik deur 'n buitegroep geïnisieer kan word, soos die geval in Port Elizabeth waar Swartes in pamflette wat onder die naam van die Uitvoerende bestuur van die SA Vakbond vir Motormonteer- en Onderdelewerkers uitgereik is, gevra word om niks wit aante hou, te eet of te drink nie. Babas moet 'Coke' drink en selfs tande moet swart gemaak word. (Die Burger, 27 Augustus 1981). Aan die anderkant word daar periodiek aanvalle teen 'sagte teikens' soos dié teen die leërkollege in Pretoria, (Die Burger, 14 Augustus 1981) en die bank in Silverton geloods. Die stedelike terreuraksies sal toenemend deur guerrilla-aktiwiteite in die platteland afgewissel word soos die gevalle by Barkly-Oos en
(Burger, 14 Augustus 1981) Elliot bewys. (Die Burger, 8 Augustus 1981).

Dit is om hierdie rede dat die regering periodiek die bevolking bewus maak van die gevare van die rewolusionêre aanslag. Hulle bekommernis is dat ons oorwinnings oor SWAPO ' $n$ valse gerustheid kan skep. (Die Burger, 15 Augustus 1981). Ter illustrasie van die tipe gevaar wat Swart Stedelike gebiede kan inhou, kan 'n parallel tussen die Amerikaanse 'ghetto' en ons Swart stede getrek word. Slegs die ligging tov die SSK verskil tussen die gebiede. Salisbury (1971) meen dat voortbestaan ' $n$ kritieke faktor tov die skepping van ' $n$ insurgente staat is. Dat Swart bewustheid geweldig vinnig toeneem, kan afgelei word van tekens soos swartmagsalute (gebalde vuis in die lug). Blankes word as onderdrukkers uitgekryt. Die Swart stad het grense en 'n kernarea. Deur slegs die paar voorbeelde te noem word die gevare aangedui. Dit is egter so dat die Swart bevolking in SA grootliks vreedsaam is en dat daar nie ' $n$ absolute homogeniteit in ons Swart gebiede is nie. Aan die anderkant tel bg feit ook nie as teen 'n gemeenskaplike vyand opgetree moet word nie. Vervolgens word na 'n paar teenmaatreëls gekyk.

\section{Teen-revolusie in die stad}

Die bekamping van guerrilla-optrede in die stad is onlosmaaklik aan dié op die platteland gekoppel. In die breë gesien, sal Suid-Afrika op vier terreine aandag moet gee ten einde ' $n$ effektiewe teenvoeter vir terrorisme te wees. Genl Viljoen (1981) meen dat die bekamping van guerrillaoorlogvoering op vier aspekte moet konsentreer waarby die strategie in die stede aansluiting vind. Eerstens is hy van mening dat SA staatkundig diplomatiek sterk moet wees. Die doelwitte van die regering moet deur doeltreffende administrasie uitgevoer en geïmplimenteer word. Verder moet alle situasies wat tot konflik lei, doeltreffend ontlont word. 'n Baie belangrike doelwit, staatkundig gesproke, is om ' $n$ aanvaarbare binnelandse bedeling te skep. Die Swartman in die stede het gekom om te bly en tot tyd en wyl sy steun en tevredenheid nie verkry word nie, is daar ' $n$ teelaarde vir kommunistiese idees. Om Suid-Afrika staatkundig te versterk is elke burger van die land se plig ongeag sy taal, ras kleur of beroep.

Tweedens moet Suid-Afrika ekonomies sterk bly. Ekonomiese vooruitgang is een van die belangrikste aspekte in de uitskakeling van kommu- 
nisme. In dié verband moet die vooruitgang na alle mense in die land uitgedra word. Werkloosheid skep groot probleme. Brittanje kan hier as voorbeeld aangehaal word met 'n geskatte 3 miljoen werkloos en die eise om 'n sosialistiese bedeling. (TV Nuus, 20 September 1981). Werkloosheid moet tot 'n minimum beperk word. Die derde aspek het betrekking op die veiligheid van die land: 'n doeltreffende weermag moet opgebou en in stand gehou word. Daardeur word verseker dat nie alleen die staat nie maar ook die bevolking beskerm kan word. Die Weermag (Polisie hier ingesluit) moet kan verhoed dat die plaaslike bevolking geïntimideer word en dat dade van terreur teen hulle gepleeg word. Seker een van die belangrikste aspekte is om te verhoed dat die mense die indruk kry dat die terroriste nie deur die veiligheidsmagte beheer kan word nie. Om die land weerbaar te maak, is kennis van jou vyand nodig - dié belangrikste voorvereiste is nie tot die veiligheidsmagte beperk nie, maar tot die hele bevolking. Laastens moet die bevolking maatskaplik/sielkundig weerbaar wees. In SA kan dit in twee kategorieë ingedeel word. Die aanslag teen die Blanke is om vrees te skep, ' $n$ gevoel dat dit nodeloos is om te stry. Teen die anderskleurige is die poging om ' $n$ rewolusionêre klimaat te skep, maw dat die huidige evolusionêre veranderings nie voldoende is nie. (Viljoen, 1981).

Die teen-rewolusionêre strategie moet deur elke landsburger toegepas word. Voorkomingsmaatreëls is noodsaaklik, maar dit moet nie geïsoleerd wees nie. Koördinasie tussen die regering, polisie en maatskappy is van kritieke belang. Stedelike guerrilla-optredes kan nie totaal uitgeskakel word nie (Schutte, 1978) en daarom is dit ook noodsaaklik dat die werkgewer in die stad alles in sy vermoë moet doen om sy werkers en kliënte te beskerm. Publisiteit ivm 'n aanslag wat afgeslaan is deur doeltreffende sekerheid, dien nie die saak van die stedelike terroris nie. Om die aspek beter uit te lig, moet ' $n$ mens kyk wat deur werkgewers, maatskappye gedoen behoort te word om enige aanslag die hoof te bied. Eerstens behoort 'n goeie sekerheidstelsel ingestel te word wat deur persone wie se bona-fides bo verdenking is, bedryf word. Tweedens moet deskundige raad deur maatskappye ingewin word tov sekerheidsmaatreëls. Derdens moet doeltreffende maatreëls teen brand ingestel word. Vierdens is waaksaamheid iets wat by werknemers ingeprent moet word. Slagoffers van bomaanvalle in openbare geboue meen dat die belangrikste aspek die besoeker aan die instansie is. Vyfdens kan verklikkers, soos X- strale aangewend word om enige wapens wat ingebring word, aan te dui. (Shannon, 1979; Flood, 1979). Die sekerheidsmaatreëls en 'n magdom ander kan aangewend word om die gebruiker en die gewone man op straat te beskerm en indirek die staat se saak te sterk of andersyds die stedelike guerrilla se saak te belemmer. Daar moet egter beklemtoon word dat stedelike terrorisme in sy volle totaliteit baie moeilik gekeer kan word. 'n Doeltreffende polisie- en weermag, die beskerming van die bevolking teen intimidasie en weerwraak, en die instelling van ' $n$ doeltreffende burgerlike beskermingsorganisasie is van die belangrikste onderdele van die teen-rewolusie. (Schutte, 1978).

In die bekamping van stedelike terrorisme veral sou so ' $n$ stad as ' $n$ insurgente basis gebruik word - is dit belangrik dat dit doeltreffend geïsoleer kan word. Omdat ' $n$ stad nie die ruimte het om landboukundig selfstandig te wees nie, is hy van die platteland afhanklik. Om hierdie rede kan 'n stad (wêreldwyd) nie dien as 'n ruimtelike basis vir ' $n$ insurgente staat nie, want dit is nie in staat om in ' $n$ verlengde stryd te wen nie.

\section{Gevolgtrekking}

Tot op hede is anti-Suid-Afrikaanse rewolusionêre groepe, in die geheel beskou, nog baie ondoeltreffend. Die optredes deur die ANC en ander groepe in die vroeë sestigerjare het grootliks agv die volgende gefaal.

- Die bevolking, veral die Blankes, is bewus gemaak van 'n gevaar en hulle het saamgestaan.

- Die Suid-Afrikaanse regering het beslis opgetree en het sake goed georganiseer.

- Die vyand was tot 'n groot mate oneffektief en geïsoleerde gevalle het voorgekom wat nie goeie aansluiting met mekaar kon vind nie. (Feit, 1970).

Vandag het die situasie nie veel verander nie. Die veiligheidsmagte het steeds goeie beheer maar allerweë word besef dat dit na die man op die straat oorgedra moet word. Dit blyk ook dat daar in die leierskap van die rewolusionêre groepe verdeeldheid bestaan. Die stryd is tussen die jonger geslag en die huidige leierskap wat van verstokte idees en 'n gebrek aan daadkrag veral in PAC geledere beskuldig word. In die ANC is die jongeres se beskuldiging dat daar geen domokratiese beginsels tov leierskap in die beweging bestaan nie en dat die leiers nie tred hou met die huidige situasie nie. 


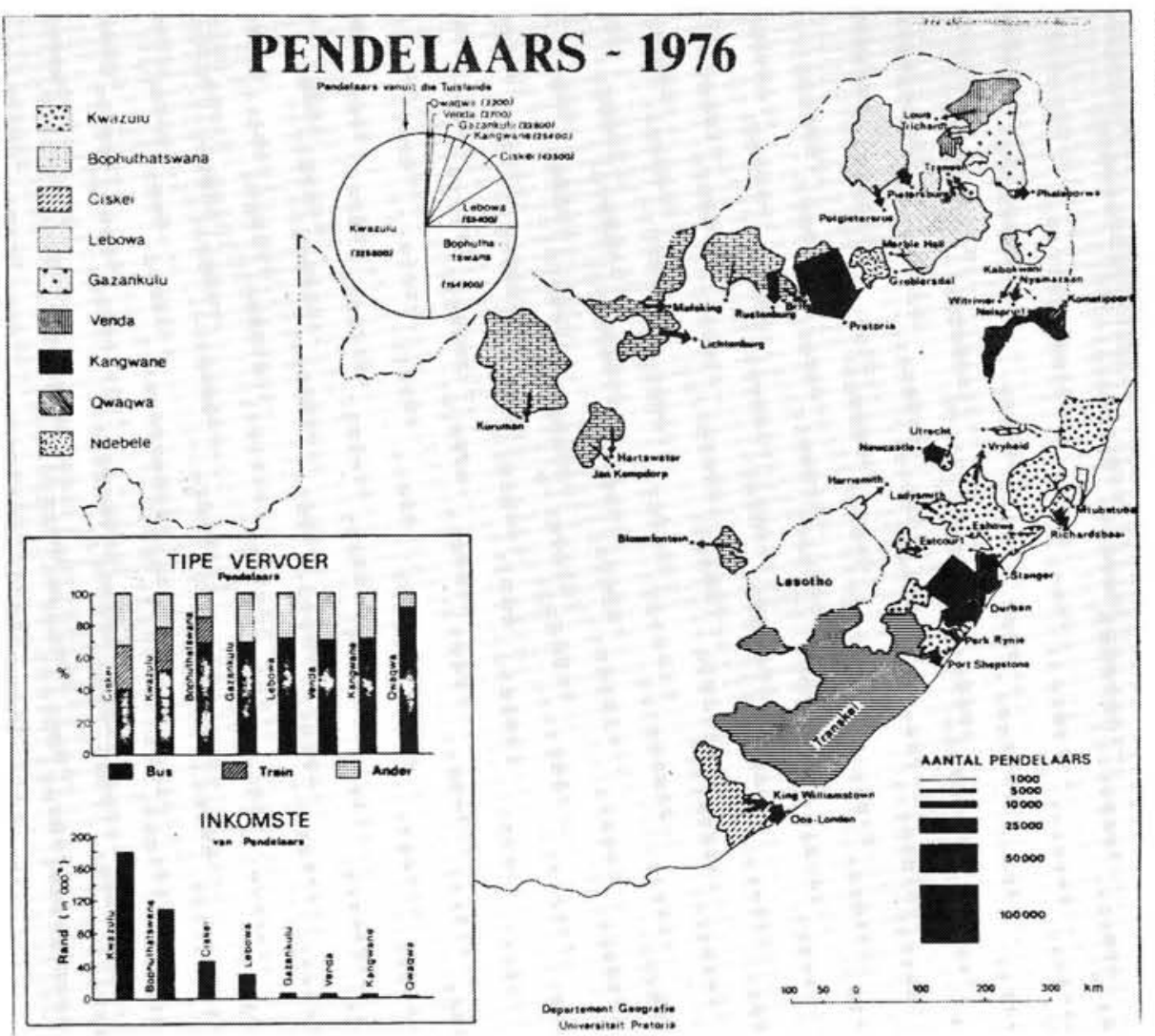

Aanhangsel A

By die Suid-Afrikaanse Stad

as ruimtelike basis vir 'n

Insurgente Staat

Pendelaars uit die Nasionale State

STEDELIKE SWART BEVOLKING 1960

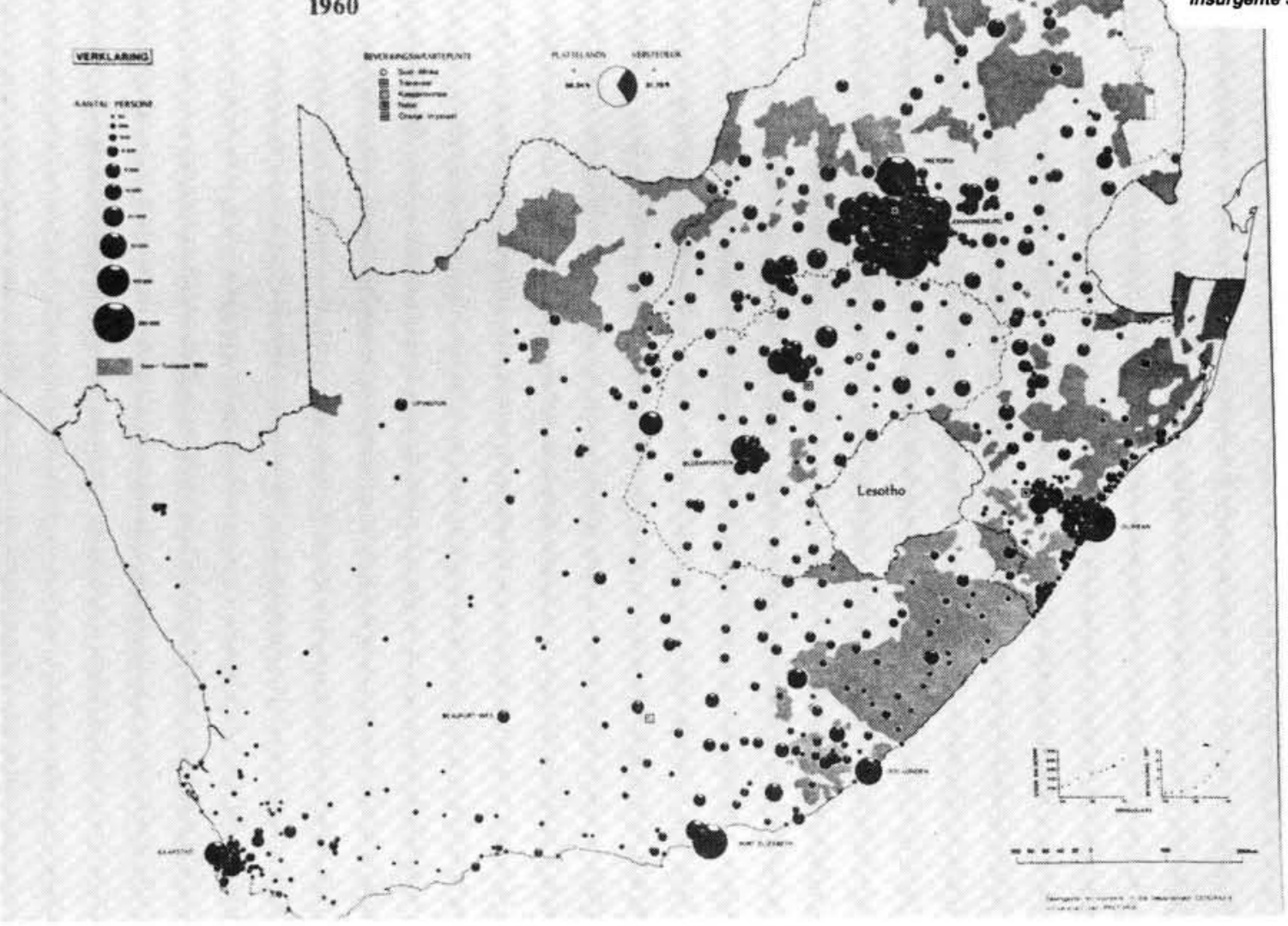

Stedelike Swart bevolking 1960 


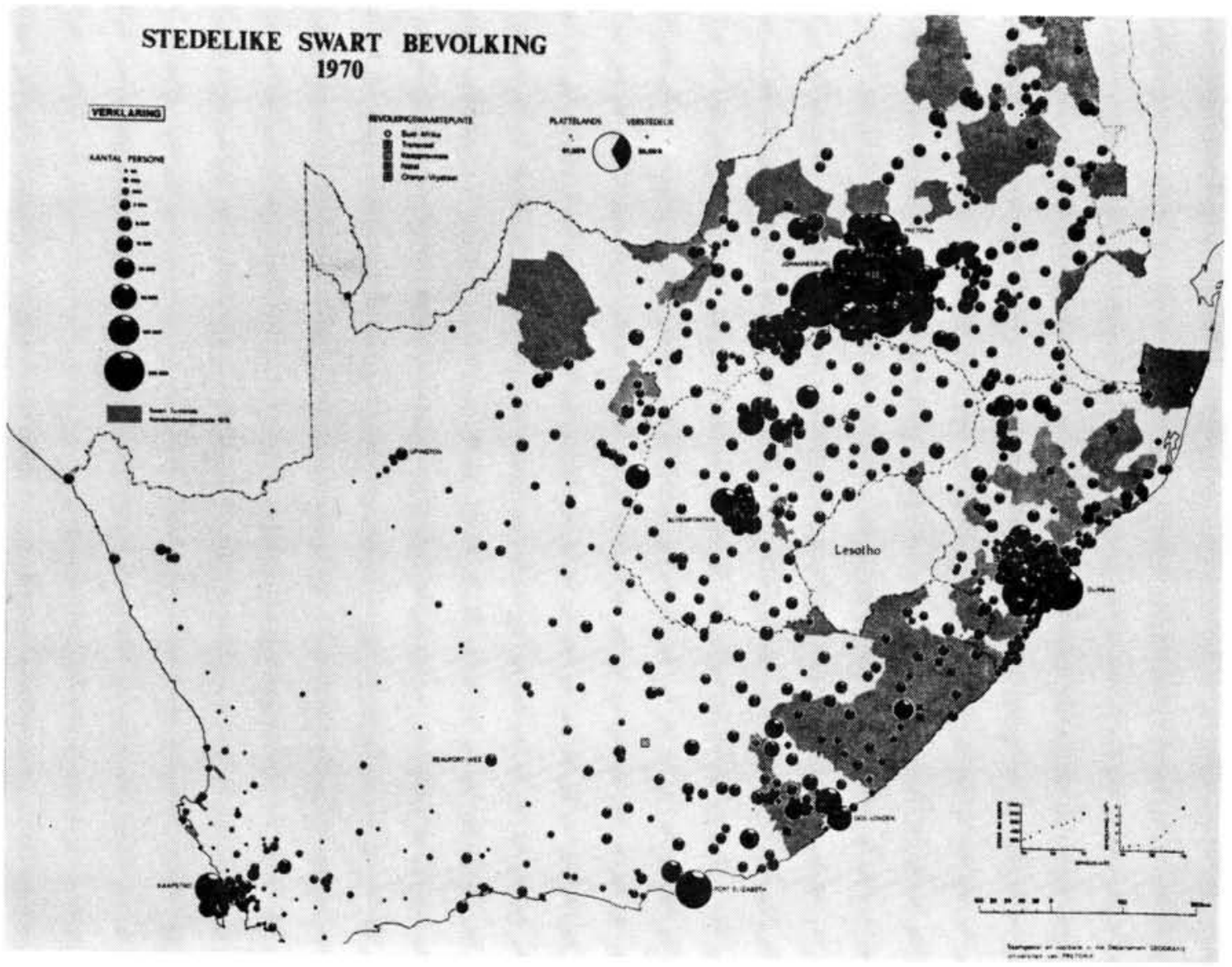

Stedellke Swart bevolking 1970

"Kapt C.C. Scheepers het in 1980 die graad B.Mil (Geesteswetenskappe) aan die Universiteit van Stellenbosch cum laude verwert en studeer tans in die graad B.Mill (Honneurs in Geografie) aan dieselfde universiteit. Hy dien tans as opleidingsoffisier aan die Militêre Akademie.

\section{Bibliografie}

\section{Boeke}

De Villiers, H.H.W. 1964. Rivionia, Operation Mayibuye. Johannesburg: Afrikaanse Pers-Boekhandel. pp. 1-118.

Hitchcock, B. 1973. Bwana Go Home. Kaapstad: Citadell Press, Londsdowne. pp. $136-140$

Lass, H.R. 1975. Die Grondleggers van Rewolusionêre Oorlogvoering. Potchefstroom: Potchefstroom Herald Bpk. pp. 149-156.

Maasdorp, B. \& A.S.B. Humphreys. 1975. From Shantytown to Township. Johannesburg. Juta and Company.

Schutte, S.H. 1978. Polisiologiese benadering van Terrorisme in SuidAfrika. Ongepubliseerde M.A. Verhandeling UNISA. Pretoria. pp. 75-79 en pp. $171-217$.

Shay, R. \& C. Vermaak. 1917. The Silent War. Salisbury: Galaxie Press. pp. $79-151$

Smit, P. \& J.J. Booysen. 1981. Swart Verstedeliking. Kaapstad: Tafelberg Uitgewers Beperk. pp. 46-107.

Strydom, L. 1964. Rivionia, Masker Af. Derde druk. Johannesburg: Voortrekkerpers. pp. 11-162

Theron, W.A. 1976. Stedelike Terrorisme. Ongepubliseerde MA Verhandeling U.O.V.S. Bloemfontein. pp. 48-70.

2. Periodieke Publikasies

Atrika Instituut Bulletin, 1979. Vol, 19, №. 7, pp. 73-73.

Burger, Die. 14 Augustus 1981. p. 1

15 Augustus 1981. p. 1

27 Augustus 1981. p. 1

Coetzee, P.J. 1979. What Industry and Commerce should be doing to Protect themselves against Civil Disturbance. People and Profits. Vol. 6. pp. 24-25.

Coetzee, P.J. 1981. Stedelike Terrorisme: Die Suid-Afrikaanse Situasie. Simposium oor die Internasionale Politieke Sentrum vir Internasionale Politiek. PU vir CHO. pp. $16-34$.
Davis, R.J. (sine anno). The Spatial formation of the South African City. Bron van Prof Barnard ontvang. pp. 1-24.

Davis, R.J. 1964. Social Distance and the Distribution of Occupational Categories in Johannesburg and Pretoria. South African Geographical Journal. Vol. 46.

Dwyer, D.J. 1978. The Third World City. Geographical Magazine. pp. $519-522$

Feit, E. 1970. Urban Revolt in South Africa: a Case Study. Journal of Modern African Studies. Vol. 8, No. 1, pp. 55-71.

Flood, K. 1979. Preventing a Terrorist Attack. Security and Protection of SA. Oktober. pp. $11-12$.

Lass, H.R. 1981. Terrorisme binne die Breër verband van Rewolusionêre Oorlogvoering. Sentrum vir Internasionale Politiek. PU vir CHO. pp. $1-15$.

Oosthuizen, A.J.G. Die Geograaf se bydrae tot die Beplanningsuitdagings van die Suid-Afrikaanse Stad. Suid-Afrikaanse Geograaf. Vol. 7. No. 2, pD. $107-115$.

Salisbury, H.G. 1971. The State Within a State: Some Comparisons between the Urban Ghetto and the Insurgent State. Professional Geographer. Vol. 23, №. 2, pp. 105-112.

Scitt, P. 1955. Cape Town: A Multi-Racial City. Geographical Journal. Vol. 21. pp. $149-157$.

Shannon, R. 1979. Violent Crime. Security and Protection of SA. Junie/ Julie. pp. $3-7$.

Smit, P. Urbanization in Africa: Lessons for Urbanization in the Homelands. SA Geographical Journal. Vol. 61. pp. 1-6

Viljoen, C.L., Genl, 1981. Suid-Afrika se Antwoord en Optrede. Simposium oor die Internasionale Politiek Sentrum vir Internasionale Politiek. $\mathrm{PU}$ vir $\mathrm{CHO}$. pp. $48-65$.

3. Ander

Barnard, L.D. 1981. Lesing te Militêre Akademie aangebied mbt SA se Veiligheidsituasie

Cillie, P.M. 1977. Verslag van die Kommissie van Ondersoek oor die Oproer in Soweto en Elders van 16 Junie 1976 tot 28 Februarie 1977. Vol. 1. Pretoria: Die Staatsdrukker. pp. 40-590. Marighella, C. 1969. Minimanual of the Urban Guerrilla. Publikasie van die SAW Sentrale Biblioteek ontvang. 